\title{
STAN I PERSPEKTYWY ORAZ UWARUNKOWANIA PRAWNE FUNKCJONOWANIA SEKTORÓW BIOPALIW TRANSPORTOWYCH W POLSCE
}

\author{
Adam Kupczyk, Joanna Mączyńska, Michał Sikora, Karol Tucki, \\ Tomasz Żelaziński
}

Katedra Organizacji i Inżynierii Produkcji Szkoły Głównej Gospodarstwa Wiejskiego w Warszawie Kierownik katedry: prof. dr hab. Adam Kupczyk

\begin{abstract}
Słowa kluczowe: biopaliwo transportowe, biokomponent, bioetanol, biodiesel, atrakcyjność sektora

Key words: transport biofiuel, bio-component, bioethanol, biodiesel, sector's attractiveness

S y n o p s i s. W opracowaniu przedstawiono stan obecny oraz przyszłość sektorów biopaliw transportowych w Polsce. Ze względu na istotne znaczenie, jakie w tej roli odgrywają uwarunkowania prawne, omówiono najważniejsze dyrektywy i ustawy wpływające na kształt omawianych sektorów. Metodą punktową, wielokryterialną M.E. Portera określono atrakcyjność krajowych sektorów biopaliw transportowych, tj. biodiesla i bioetanolu z surowców jadalnych (tzw. biopaliw 1. generacji) oraz bioetanolu z surowców niejadalnych - przede wszystkim lignocelulozy (biopaliwo 2. generacji). Wiele czynników występujących w makro- i mikrootoczeniu sektorów biopaliw 1. generacji powoduje, że ich atrakcyjność systematycznie maleje. Natomiast sektor bioetanolu 2. generacji, którego obecnie produkcja w Polsce nie występuje w skali przemysłowej, charakteryzuje się stosunkowo wysoką i rosnącą atrakcyjnością.
\end{abstract}

\section{WSTĘP}

Stały rozwój cywilizacji stymuluje zwiększenie zużycia pierwotnych nośników energii. Paliwa kopalne, które obecnie w największym stopniu są wykorzystywane do produkcji energii elektrycznej, ciepła i jako paliwa w transporcie, są źródłami wyczerpywalnymi, a ich eksploatacja i energetyczne użycie mają negatywny wpływ na środowisko naturalne [Koć, Osiak 2016, Kuziemska i in. 2015]. Zrównoważony rozwój gospodarczy oparty jest na założeniu świadomego kształtowania relacji między wzrostem gospodarczym i troską o środowisko naturalne, co skutkuje obowiązkiem racjonalnego oraz efektywnego gospodarowania zasobami naturalnymi. W związku z tym coraz większą uwagę przywiązuje się do rozwoju oraz intensyfikacji wykorzystania odnawialnych źródeł energii (OZE).

Sektor transportu, stanowiący jeden z kluczowych sektorów dla rozwoju gospodarki, jest znaczącym konsumentem energii oraz istotnym emitentem zanieczyszczeń. W tym sektorze elementem odpowiedzialnym za najwyższą emisję zanieczyszczeń jest transport drogowy [Pielecha, Markiesz-Guranowska 2014]. W związku z tym realizowana polityka energetyczno-klimatyczna Unii Europejskiej (UE) jest oparta na dążeniu do zrównowa- 
żonego rozwoju transportu oraz ograniczenia jego negatywnego wpływu na środowisko naturalne. W tym zakresie podstawowym instrumentem jest integrowanie polityki transportowej z ekologiczną [Kowalski 2014], czego wyrazem jest m.in. propagowanie wykorzystania biopaliw transportowych.

Pierwsze biopaliwa transportowe zostały wyprodukowane na początku ubiegłego stulecia. W przedwojennej Polsce zdolności w zakresie produkcji etanolu technicznego (transportowego) osiągały poziom nawet $10 \mathrm{mln}$ 1/rok [Jarosz 2010]. Jednak z uwagi na niską cenę ropy naftowej paliwa alternatywne nie zostały rozpowszechnione. W Polsce w latach 90. XX wieku opanowano technologię blendowania bioetanolu z benzyną.

Obecny kształt oraz potencjał sektorów biopaliw transportowych jest efektem przede wszystkim akcesji Polski do struktur UE. Wówczas krajowe otoczenie prawne zaczęło ewoluować w kierunku implementacji prawa unijnego (co trwa do dziś). Pojawiły się zachęty do inwestowania w sektory biokomponentów oraz towarzyszący im ogromny optymizm, wzmacniany dodatkowo znaczącymi ulgami akcyzowymi. Jednak z czasem optymizm się zmniejszał, co wynikało ze zmniejszających się zwolnień akcyzowych (całkowity zanik w maju 2011 r.), wzrastających wymagań jakościowych oraz znaczącego udziału importowanych biopaliw [Borowski i in. 2014].

W prawodawstwie krajowym definicja biopaliw ciekłych, nazywanych biopaliwami transportowymi, zawarta jest m.in. w Ustawie o biokomponentach i biopaliwach ciektych [Dz.U.2015.755, Dz.U.2016.266, DZ.U.2016.1165]. Zgodnie z nią, do paliw ciekłych zaliczane są:

- benzyny silnikowe zawierające powyżej 10\% objętości biokomponentów lub powyżej $22 \%$ objętości eterów, o których mowa w pkt 4 . ustawy,

- olej napędowy zawierający powyżej 7\% objętości biokomponentów,

- bioetanol, biometanol, biobutanol, ester, bioeter dimetylowy, czysty olej roślinny, biowęglowodory ciekłe, biopropan-butan, skroplony biometan, sprężony biometan oraz biowodór - stanowiące samoistne paliwa.

\section{CEL, ZAKRES I METODYKA PRACY}

Głównym celem pracy jest rozpoznanie obecnego stanu oraz perspektyw rozwoju sektorów biopaliw transportowych w Polsce. Szczególną uwagę zwrócono na aspekty prawne, które są jednym z najistotniejszych czynników warunkujących funkcjonowanie i stymulujących rozwój omawianych sektorów. Celem uzupełniającym jest określenie atrakcyjności krajowych sektorów biopaliw transportowych w 2016 r. Uzyskane wyniki odniesiono do wyników badań z poprzednich lat (2007-2015).

Zakres pracy obejmuje polskie sektory biopaliw transportowych, tj. sektor produkcji bioetanolu oraz estrów metylowych (produkowanych przede wszystkim z surowców spożywczych). Cel zrealizowano na podstawie przeglądu literatury przedmiotu oraz analizy danych statystycznych z raportów, rejestrów oraz materiałów udostępnianych na stronach internetowych. W celu określenia atrakcyjności sektorów posłużono się punktową, wielokryterialną metodą M.E. Portera. 


\title{
ASPEKTY PRAWNE FUNKCJONOWANIA SEKTORÓW BIOPALIW TRANSPORTOWYCH I WYNIKAJĄCE Z NICH WYZWANIA NA NAJBLIŻSZE LATA
}

\begin{abstract}
Regulacje prawne dotyczące polskiego rynku biopaliw transportowych warunkowane są i regularnie przystosowywane do regulacji prawnych UE. Przepisy europejskich dyrektyw zobowiązały państwa członkowskie do podejmowania działań mających na celu osiągnięcie określonego udziału biopaliw w transporcie oraz redukcji emisji gazów cieplarnianych. Na podstawie unijnych dyrektyw wprowadzono do polskiego prawodawstwa ustawy implementujące wymagania UE. Spośród regulacji prawnych dotyczących sektorów biopaliw transportowych w Polce najistotniejsze znaczenie miały dyrektywa 2003/30/WE [Dz.U.UE.L.2003.123.42], zmieniona w 2009 r. dyrektywą 2009/28/WE (tzw. dyrektywa RED) [Dz.U.UE.L.09.140.16] oraz kolejna dyrektywa wprowadzona w tym samym roku, a mianowicie dyrektywa 2009/30/WE (tzw. dyrektywa FQD) [Dz.U.UE.L.2009.140.88]. Zgodnie z pierwszą z dyrektyw, państwa członkowskie zobligowane są do osiągnięcia w 2020 r. udziału minimum 10\% energii pochodzącej ze źródeł odnawialnych w końcowym zużyciu energii w transporcie. Aby zrealizować to zalecenie, do polskiego prawodawstwa wprowadzono tzw. narodowy cel wskaźnikowy (NCW) [Taras 2016], czyli określony na każdy rok kalendarzowy minimalny udział biokomponentów oraz innych paliw odnawialnych w ilości paliw zużywanych w ciągu tego roku w transporcie, liczony według wartości opałowej. Dodatkowo omawiana dyrektywa kładzie nacisk na zrównoważony charakter produkcji biopaliw oraz biopłynów, wprowadzając tzw. kryteria zrównoważonego rozwoju (KZR), spośród których jednym z ważniejszych jest wymóg ograniczenia emisji gazów cieplarnianych w pełnym cyklu ich produkcji ${ }^{1}$ [Żak i in. 2014]. Dyrektywa FQD wprowadziła wskaźnik o nazwie narodowy cel redukcyjny (NCR), który określa minimalną wymaganą wartość ograniczenia emisji gazów cieplarnianych w cyklu życia paliw stosowanych w transporcie, w przeliczeniu na jednostkę energii. Na państwa, które nie osiągną w $2020 \mathrm{r}$. minimalnych wartości wskaźników NCW oraz NCR (10 i 6\%), nakładane będą wysokie kary finansowe (około 4 i 8 euro/litr brakujący do wykonania wskaźnika).

Unijne wymagania zawarte w omawianych dyrektywach, dotyczące m.in. udziału energii ze źródeł odnawialnych w transporcie, NCW, KZR, NCR oraz promocji odnawialnych źródeł energii, zaczęto stopniowo implementować do polskiego prawodawstwa od 2006 r. wdrażając Ustawę z dnia 25 sierpnia 2006 r. o biokomponentach i biopaliwach ciektych [Dz.U.2006.169.1199] oraz Ustawę z dnia 25 sierpnia 2006 r. o systemie monitorowania i kontrolowania jakości paliw [Dz.U.2006.169.1200], a następnie regularnie nowelizując wprowadzone ustawy. Stan prawny obowiązujący w 2016 roku to ujednolicony tekst Ustawy z dnia 25 sierpnia 2006 r. o biokomponentach $i$ biopaliwach ciektych [Dz.U.2015.775, Dz.U.2016.266, Dz.U.2016.1165) uwzględniający zmiany wprowadzone w 2015 oraz 2016 r. oraz ujednolicony tekst Ustawy z dnia 25 sierpnia 2006 r. o systemie monitorowania i kontrolowania jakości paliw [Dz.U.2014.1728, Dz.U.2015.1361, Dz.U.2016.266, 542, 1165] uwzględniający zmiany dokonywane w treści aktu do 2016 r.

Największe wyzwanie dla polskiego rynku biopaliw transportowych to najnowsza dyrektywa UE - Dyrektywa Parlamentu Europejskiego i Rady z dnia 9 września 2015 r. zmieniająca Dyrektywę 98/70/WE dotyczaca jakości benzyny i olejów napędowych oraz
\end{abstract}

\footnotetext{
Pojęcie emisji gazów cieplarnianych w pełnym cyklu produkcji paliw rozumiane jest jako suma emisji powstających na każdym etapie cyklu życia paliwa - od wydobycia lub uprawy, poprzez zmianę sposobu użytkowania gruntów, transport, dystrybucję, przetwarzanie oraz spalanie.
} 
Dyrektywe 2009/28/WE w sprawie promowania stosowania energii ze źródet odnawialnych-dyrektywa 2015/1513/WE. Podstawę zmian dokonanych w tej dyrektywie stanowi przywołana w preambule teza, że w sytuacji, w której obszary wykorzystywane wcześniej na potrzeby rynków żywnościowych oraz paszowych zostają następnie przeznaczane pod produkcję biopaliw, zapotrzebowanie na produkty z pierwszej grupy musi być zaspokajane przez intensyfikację bieżącej produkcji bądź przeznaczanie pod produkcję gruntów niestanowiących użytków rolnych. Ostatni przypadek, co podkreślono w dyrektywie, stanowi tzw. ILUC (ang. indirect land use change), czyli pośrednia zmiana sposobu użytkowania gruntów, i jeśli wiąże się z przekształceniem terenów o dużych zasobach węgla, prowadzić może do znacznych emisji gazów cieplarnianych. Konieczność znalezienia rozwiązań umożliwiających zmniejszenie niekorzystnych skutków związanych z ILUC stanowi podstawę nowych regulacji [Wąsiewski 2015].

Jedną z najistotniejszych zmian, którą wprowadza dyrektywa, jest ustanowienie, że w celu obliczania udziału energii powstającej przy wykorzystaniu źródeł odnawialnych we wszystkich rodzajach transportu (wyznaczony cel to minimum $10 \% \mathrm{w} 2020 \mathrm{r}$.) maksymalna ilość biopaliw 1. generacji nie może przekraczać 7\%. Jak wskazano w preambule, ograniczenie biopaliw tej generacji, czyli powstających przy udziale surowców spożywczych, pozwoli zmniejszyć skutki ILUC oraz przygotować proces przejścia na biopaliwa zaawansowane wyższych generacji (niestanowiących konkurencji upraw roślin spożywczych).

Dodatkowo, co także wskazano w preambule dyrektywy, konieczne jest wspieranie przez państwa UE badań oraz rozwoju nowych, zaawansowanych biopaliw, m.in. takich jak biopaliwa wytwarzane z odpadów czy alg. Promocji zaawansowanych biopaliw służyć ma również system podwójnego zaliczania, polegający na uznawaniu za dwukrotnie wyższy, na potrzeby realizacji unijnego celu, udział biopaliw powstających przy udziale wykazanych w dyrektywie surowców (m.in. słomy, frakcji biomasy, zmieszanych odpadów komunalnych oraz bioodpadów $)^{2}$. W ramach wspierania nowoczesnych biopaliw państwa członkowskie powinny dodatkowo do 6 kwietnia 2017 r. ustalić krajowe cele w zakresie ich wykorzystania [Wąsiewski 2015].

Skuteczność wprowadzanych środków (zwłaszcza w zakresie ILUC), a także funkcjonowanie rynku biopaliw transportowych będą poddawane kolejnym analizom, co będzie pociągać za sobą konieczność nałożenia nowych obowiązków sprawozdawczych. Skutkiem zapowiedzianych analiz może być m.in. modyfikacja KZR.

Transpozycja postanowień najnowszej dyrektywy do krajowych porządków prawnych państw członkowskich powinna zostać ukończona najpóźniej do 10 września 2017 r. [Wąsiewski 2015]. W związku z tym w Polsce powstał już Projekt ustawy o zmianie ustawy o biokomponentach i biopaliwach cieklych oraz niektórych innych ustaw, uwzględniający najnowsze wymagania UE. Pierwotnie termin przyjęcia projektu planowany był na 1 stycznia 2017 r., jednak termin ten nie został dotrzymany. Trudno wskazać, kiedy projekt zostanie przyjęty. Problem ten budzi wiele kontrowersji wśród podmiotów działających w sektorach biopaliw.

2 Kwestia ta częściowo została już wdrożona do polskiego prawodawstwa w obowiązującej ustawie o biokomponentach i biopaliwach ciekłych, która ustanawia, że udział biokomponentów wytworzonych z odpadów, pozostałości, niespożywczego materiału celulozowego oraz materiału lignocelulozowego, liczony według wartości opałowej na potrzeby realizacji NCW uznaje się za dwukrotnie wyższy. 


\section{PODSTAWOWE INFORMACJE ZWIĄZANE ZE ZDOLNOŚCIAMI PRODUKCYJNYMI BIOPALIW TRANSPORTOWYCH W POLSCE}

Ze względu, że rynek biopaliw transportowych w Polsce bazuje na stosowaniu mieszkanek paliwowych będących połączeniem paliw konwencjonalnych oraz biokomponentów (benzyny z domieszką bioetanolu oraz olej napędowy z dodatkiem estrów metylowych, tzw. biodiesel), w dalszej części opracowania przedstawiono podstawowe dane związane z produkcją biokomponentów w Polsce.

Zgodnie z obowiązującymi w Polsce uwarunkowaniami prawnymi [Dz.U.2015.775 ze zm.] działalność gospodarcza związana z wytwarzaniem, magazynowaniem lub wprowadzaniem do obrotu biokomponentów wymaga uzyskania wpisu do rejestru wytwórców prowadzanego przez Prezesa Agencji Rynku Rolnego (ARR). Do 7.07.2016 r. do rejestru wpisanych było 25 podmiotów, z których 13 to zakłady zajmujące się wytwarzaniem bioetanolu (zadeklarowana zdolność produkcyjna 648 tys. t), 12 - estrów metylowych (zadeklarowana zdolność produkcyjna 1147 tys. t) ${ }^{3}$ oraz 1 - węglowodorów syntetycznych. Produkcję bioetanolu i estrów metylowych za lata 2010-2016 oraz deklarowane przez wpisane do rejestru podmioty roczne zdolności produkcyjne zestawiono w tabeli 1.

Poza deklarowanymi przez wytwórców teoretycznymi możliwościami produkcji biokomponentów istotne znaczenie ma faktyczny stopień ich wykorzystania. Z zestawienia w tabeli 1. wynika, że potencjał wytwórczy polskich producentów biokomponentów był wykorzystywany jedynie w nieznacznym stopniu - w przypadku bioetanolu w analizowanym okresie na poziomie $27 \%$, natomiast estru metylowego na poziomie $57 \%$. Polski rynek biokomponentów zdominowany jest przez ester metylowy, a jego produkcja od $2012 \mathrm{r}$. przewyższa deklarowane zdolności wytwarzania bioetanolu.

Podstawowymi surowcami wykorzystywanymi przez wytwórców do produkcji bioetanolu są kukurydza, destylat rolniczy oraz alkohol etylowy. Estry metylowe wytwarzane są przede wszystkim z wykorzystaniem oleju rzepakowego, rzepaku oraz thuszczy wytopionych kat. III. W pierwszej połowie 2016 r. polskie zakłady produkujące bioetanol

Tabela 1. Zdolności produkcyjne wytwórców biokomponentów i stopień ich wykorzystania w Polsce w latach 2010-2015

\begin{tabular}{lrrrrrrr}
\hline Wyszczególnienie & \multicolumn{7}{c}{ Wielkości [tys. t] w roku } \\
\cline { 2 - 8 } & 2010 & 2011 & 2012 & 2013 & 2014 & 2015 & $2016^{*}$ \\
\hline Zadeklarowane zdolności produkcyjne & 589 & 604 & 594 & 594 & 585 & 575 & 648 \\
wytwórców bioetanolu & 157 & 132 & 169 & 186 & 143 & 168 & . \\
Produkcja bioetanolu & 828 & 848 & 1012 & 1024 & 1111 & 1126 & 1147 \\
Zadeklarowane zdolności produkcyjne & 368 & 361 & 602 & 654 & 693 & 758 & . \\
wytwórców estru metylowego & & & & & &
\end{tabular}

${ }^{*}$ Dotyczy stanu na 07.07.2016 r.

Źródło: opracowanie własne na podstawie danych ARR - rejestrów wytwórców oraz danych dotyczących działalności wytwórców biokomponentów [http://www.arr.gov.pl].

Jedno z przedsiębiorstw wpisanych do rejestru wykonuje działalność zarówno w zakresie wytwarzania bioetanolu, jak i estrów metylowych, w związku z tym zostało uwzględnione dwukrotnie. 
W większości otrzymywały go z ziarna kukurydzy (wykorzystanie surowca na poziomie 191 tys. t), natomiast w zakładach wytwarzających estry metylowe jako surowiec w największym stopniu stosowano olej rzepakowy (406,65 tys. t). W tabeli 2. przestawiono podstawowe surowce służące do produkcji biokomponentów w Polsce, ich wykorzystanie oraz ilość wytworzonego przy ich udziale bioetanolu oraz estru metylowego w 2015 r. i pierwszej połowie $2016 \mathrm{r}$.

Tabela 2. Podstawowe surowce wykorzystane do produkcji biokomponentów w Polsce oraz ilość wytworzonego z nich bioetanolu i estru metylowego w 2015 r. oraz I połowie 2016 r.*

\begin{tabular}{|c|c|c|c|c|c|c|c|c|c|}
\hline \multirow{4}{*}{$\begin{array}{l}\text { Ro- } \\
\text { dzaj }\end{array}$} & \multirow{4}{*}{$\begin{array}{l}\text { Nazwa } \\
\text { surowca }\end{array}$} & \multicolumn{8}{|c|}{ Wielkości [tys. t] w roku } \\
\hline & & \multicolumn{6}{|c|}{2015} & \multirow{2}{*}{\multicolumn{2}{|c|}{$\begin{array}{c}2016 \\
\text { I połowa }\end{array}$}} \\
\hline & & \multicolumn{2}{|c|}{ I połowa } & \multicolumn{2}{|c|}{ II połowa } & \multicolumn{2}{|c|}{ suma za 2015} & & \\
\hline & & $\begin{array}{c}\text { ilość } \\
\text { zużytego } \\
\text { surowca }\end{array}$ & $\begin{array}{l}\text { produ- } \\
\text { kcja }\end{array}$ & $\begin{array}{c}\text { ilość } \\
\text { zużytego } \\
\text { surowca }\end{array}$ & $\begin{array}{c}\text { produ- } \\
\text { kcja }\end{array}$ & $\begin{array}{c}\text { ilość } \\
\text { zużytego } \\
\text { surowca }\end{array}$ & $\begin{array}{l}\text { produ- } \\
\text { kcja }\end{array}$ & $\begin{array}{c}\text { ilość } \\
\text { zużytego } \\
\text { surowca }\end{array}$ & $\begin{array}{c}\text { produ- } \\
\text { kcja }\end{array}$ \\
\hline \multirow{7}{*}{ 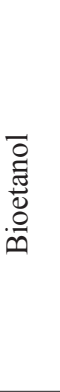 } & kukurydza & 179,37 & & 155,07 & & 334,44 & & 191,00 & \\
\hline & $\begin{array}{l}\text { destylat } \\
\text { rolniczy }\end{array}$ & 22,86 & & 21,09 & & 43,95 & & 21,41 & \\
\hline & alkohol & 15,21 & ४ & 13,68 & & 28,89 & $\infty$ & 8,52 & \\
\hline & melasa & - & $\underset{\infty}{\sigma_{n}}$ & - & $\overbrace{\infty}^{+}$ & - & $\hat{\sigma}$ & 6,26 & å \\
\hline & porektyfikat & 1,95 & & 2,93 & & 4,88 & & 3,98 & \\
\hline & $\begin{array}{l}\text { odpady } \\
\text { spożywcze }\end{array}$ & - & & - & & - & & 0,50 & \\
\hline & inny etanol $^{* *}$ & - & & - & & - & & 0,04 & \\
\hline \multirow{7}{*}{ 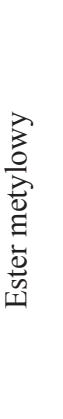 } & $\begin{array}{l}\text { olej } \\
\text { rzepakowy }\end{array}$ & 381,56 & \multirow{7}{*}{$\begin{array}{l}n \\
\infty \\
\infty \\
\infty \\
n\end{array}$} & 371,10 & \multirow{7}{*}{$\begin{array}{l}\stackrel{0}{a} \\
\text { సे } \\
\text { nn }\end{array}$} & 752,66 & \multirow{7}{*}{$\begin{array}{l}\infty \\
i n \\
i n\end{array}$} & 406,65 & \multirow{7}{*}{$\begin{array}{l}\text { o } \\
\text { ñ. } \\
\text { ơ }\end{array}$} \\
\hline & rzepak & 5,92 & & 1,24 & & 7,16 & & - & \\
\hline & thuszcz & 0,54 & & 1,75 & & 2,29 & & 0,79 & \\
\hline & $\begin{array}{l}\text { wytopiony } \\
\text { kat. III }\end{array}$ & & & & & & & & \\
\hline & $\begin{array}{l}\text { kwasy } \\
\text { tłuszczowe }\end{array}$ & 0,65 & & 1,22 & & 1,87 & & 0,18 & \\
\hline & olej zużyty & 0,22 & & 0,41 & & 0,63 & & - & \\
\hline & $\begin{array}{l}\text { ACID } \\
\text { FAME }^{* * *}\end{array}$ & - & & 0,08 & & 0,08 & & 0,11 & \\
\hline
\end{tabular}

* Uwzględniono jedynie surowce oraz wytworzone z nich biokomponenty spełniające kryteria zrównoważonego rozwoju; ${ }^{* *}$ etanol z surowców i produktów nienadających się do spożycia i przetwórstwa; ${ }^{* * *}$ ACID FAME - estry metylowe niespełniające wymagań jakościowych dla biokomponentów.

Źródło: opracowanie własne na podstawie sprawozdań kwartalnych składanych do ARR przez wytwórców biokomponentów (stan na 12.09.2016 r.) zamieszczonych na stronie internetowej ARR. 


\section{UDZIAŁ ENERGII Z OZE W KRAJOWYM TRANSPORCIE ORAZ STOPIEŃ REALIZACJI NCW}

W celu oceny wielkości wykorzystania energii z odnawialnych źródeł w krajowym transporcie jej udział w latach 2010-2015 zestawiono z adekwatnymi narodowymi celami wskaźnikowymi (rys. 1.). Od 2012 r. Polska nie osiągała ustalonych poziomów wskaźnika NCW wymaganych przepisami rozporządzenia Rady Ministrów [Rozporządzenie Rady Ministrów z dnia 23 lipca 2013 $r$. $w$ sprawie Narodowych Celów Wskaźnikowych na lata 2013-2018,

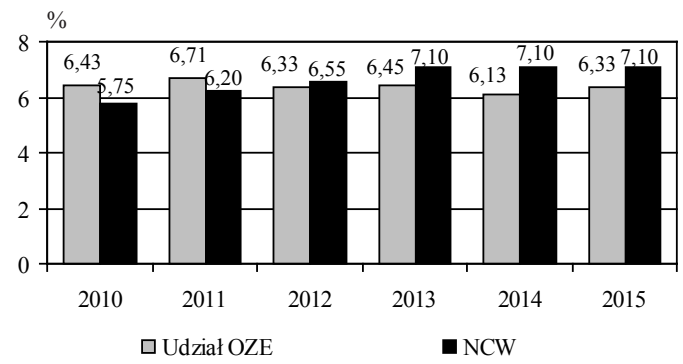

Rysunek 1. Udział energii z OZE w transporcie oraz narodowe cele wskaźnikowe w Polsce w latach 2010-2015

Źródło: [Wiśniewski 2016a]. Dz.U.2013.918]. W 2015 r. zamiast zapisanych w rozporządzeniu 7,10\%, udział energii z OZE w transporcie wynosił 6,33\%, co wynika z tzw. współczynnika redukcyjnego. Wprowadzony ustawowo [Ustawa z dnia 27 maja 2011 r. o zmianie ustawy o systemie monitorowania i kontrolowania jakości paliw oraz niektórych innych ustaw, Dz.U. 2011.153.902] w 2011 r. współczynnik pozwala producentom paliw na obniżenie wymaganego poziomu NCW. Początkowo w ustawie współczynnik ustalono w wysokości 0,85 na lata 2012-2013. Następnie w rozporządzeniach [Rozporządzenie Rady Ministrów z dnia 13 sierpnia 2013 r. w sprawie wysokości wspótczynników redukcyjnych na lata 2014 i 2015, Dz.U.2013.1052 oraz Rozporządzenie Rady Ministrów z dnia 20 kwietnia 2015 r. w sprawie wysokości współczynników redukcyjnych na lata 2016 i 2017, Dz.U.2015.631] współczynnik określono na tym samym poziomie na lata 2014-2016 i w wysokości 0,82 na 2017 r. Oznacza to, że po uwzględnieniu redukcji w 2015 r. cel wynosił 6,04\%. Najwyższa Izba Kontroli przestrzega, że osiągnięcie przez Polskę wyznaczonego przez UE celu na 2020 r. może być utrudnione [NIK 2014].

Ścieżki dojścia do wymaganego przez UE minimalnego udziału energii z OZE w poszczególnych krajach różnią się. Polska wśród 25 państw UE, które ustanowiły obowiązkowe cele na 2014 r., znajdowała się w czołówce, zajmując 2. miejsce. Przed Polską znajdowała się jedynie Francja (z ustanowionym 7,57\% udziałem). Średni ustalony minimalny poziom zużycia biopaliw w transporcie w UE w 2014 r. wynosił 5,15\% [EurObserv'ER 2015].

\section{WPŁYW KRAJOWYCH SEKTORÓW BIOPALIW TRANSPORTOWYCH NA ROLNICTWO}

W obliczu wyzwań wprowadzonych dyrektywą 2015/1513/WE oraz istotnego wykorzystania surowców pochodzących z upraw rolniczych należy podkreślić pozytywną rolę, jaką krajowe sektory biopaliw transportowych odgrywają $\mathrm{w}$ stabilizacji sytuacji $\mathrm{w}$ rolnictwie oraz rozwoju obszarów wiejskich.

Produkcja biopaliw z surowców spożywczych (tzw. biopaliw 1. generacji) stanowi bodziec dla rozwoju rolnictwa. Wynika to przede wszystkim z generowanego w ten sposób popytu na surowce rolne, przede wszystkim rzepak i kukurydzę [Żołądkiewicz 2016]. 
W 2015 r. uprawa rzepaku w Polsce zajmowała powierzchnię prawie 950 tys. ha, natomiast kukurydzy ponad 670 tys. ha [GUS 2016] (oznacza to dwukrotny wzrost areału tych gatunków względem 2005 r.).

Dodatkowy popyt prowadzi do wzrostu dochodów rolniczych i przyczynia się do zmniejszenia dysproporcji dochodowych pomiędzy osobami pracującymi w rolnictwie a zatrudnionymi w pozostałych sektorach. Dodatkowo staje się on impulsem do tworzenia na obszarach wiejskich nowych miejsc pracy.

Ponadto do pozytywnych aspektów wynikających z produkcji biopaliw ciekłych zaliczyć można stabilizację cen na rynkach surowców rolnych stosowanych do produkcji biopaliw, wynikającą z możliwości ewentualnego zagospodarowania nadwyżek danych surowców [Żołądkiewicz 2016].

W 2016 r. polski przemysł olejarski w prawie 70\% pracował na rzecz branży wytwórczej biopaliw (produkcja estrów metylowych). Bez tak znaczącego odbiorcy, z uwagi na stosunkowo stabilną sytuację na rynku olejów spożywczych, przemysł ten prawdopodobnie zmuszony byłby do ograniczenia skali przerobu. Sektory związane z produkcją biokomponentów stanowią efektywny ekonomicznie kierunek alternatywnego zagospodarowania krajowego potencjału przetwórczego, a co za tym idzie, krajowego rolnictwa [Szeliga 2016].

Rozwiązania łączące się z koniecznością ograniczenia wykorzystania surowców konwencjonalnych (spożywczych) mogą przyczyniać się do redukcji produkcji rzepaku o około $2 \mathrm{mln}$ t. Prawdopodobnym skutkiem takiej sytuacji byłoby zastąpienie produkcji rzepaku produkcją zbóż, co spowodowałoby powstanie dodatkowej podaży ziarna, przekładającej się na istotny spadek cen surowców oraz dochodów rolniczych ${ }^{4}$. Taka zmiana oznaczałaby również spadek produkcji śruty rzepakowej (o około 1,2 mln t), a to pogłębiłoby uzależnienie produkcji zwierzęcej od importu. Dodatkowo należy wskazać istotne znaczenie rzepaku w płodozmianie - ograniczenie jego powierzchni uprawy może prowadzić do powstawania monokultur zbożowych, szkodliwych z punktu widzenia kultury rolnej [Kuczyński 2016]. W związku z tym, w sytuacji nowych wyzwań rynkowych i środowiskowych istnieje konieczność wspierania branży biopaliw odpowiednimi rozwiązanymi pomocowymi i prawnymi.

\section{ZATRUDNIENIE W SEKTORACH BIOPALIW TRANSPORTOWYCH W POLSCE ${ }^{5}$}

Miejsca pracy związane z OZE wpisują się w szeroko ujmowane zagadnienia ochrony środowiska oraz promocji zrównoważonego rozwoju. W sektorach powiązanych z OZE są tworzone tzw. zielone miejsca pracy, określane niekiedy ,zielonymi kołnierzykami”, które funkcjonują w ramach zielonej gospodarki. Z raportu Komisji Europejskiej pt. „Ewaluacja potencjału zielonych miejsc pracy w kolejnych Wieloletnich Ramach Finansowych" wynika, że inwestowanie w sektory OZE przynosi pozytywne efekty dla rynku pracy [Gostomczyk 2013]. Zatrudnienie w sektorach związanych z OZE stanowi kumulację wielu zróżnicowanych procesów, działań oraz czynności, które składają się na ostateczny efekt - proekologiczną energię elektryczną, ciepło oraz paliwa transportowe.

Szacuje się, że w krajowych sektorach związanych z produkcją surowców (surowce

$4 \quad$ W konsekwencji to może prowadzić do konieczności ponownego uruchomienia skupu interwencyjnego oraz dopłat $z$ budżetu.

$5 \quad$ W odniesieniu do zatrudnienia w sektorach związanych z produkcją biopaliw transportowych nie ma jednoznacznych, zagregowanych danych. W związku z tym w pracy wykorzystano rozproszone dane, pochodzące z różnych źródeł, przede wszystkim od ekspertów branżowych [Borowski i in. 2014]. 
rolne), półproduktów (np. gorzelnie rolnicze, tłocznie) oraz zakładów produkujących biokomponenty (bioetanol, biodiesel) zatrudnionych jest 60-65 tys. osób [Zakrzewski 2014, Arcipowska i in. 2013]. Jeśli rosnący trend związany z wykorzystywaniem biopaliw zostanie utrzymany, to w perspektywie do 2020 r. przewiduje się, że liczba ta zwiększy się dwukrotnie. Bezpośrednio w zakładach zajmujących się produkcją bioetanolu oraz biodiesla zatrudnionych jest około 1000 osób [Zamojski 2014].

W latach 2008-2012 obniżyła się liczba etatów w gorzelniach rolniczych, w których produkowano alkohol etylowy (półprodukt do wytwarzania bioetanolu). Taka sytuacja wynika z obserwowanego od lat spadku liczby takich zakładów funkcjonujących na terenie Polski. Dodatkowo odnotowano spadek zatrudnienia przy produkcji oleju (do 3 tys. etatów z poziomu 3,2 tys. w 2008 r.). Stałym poziomem zatrudnienia charakteryzowało się otoczenie przemysłu olejarskiego (1,2-1,5 tys. etatów). Konieczność wytwarzania biopaliw ciekłych w składzie podatkowym oraz wynikające z niego obowiązki administracyjne powodują, że w Polsce nie zaobserwowano zainteresowania rolników wytwarzaniem biopaliw transportowych na użytek własny. Tym samym nie są tworzone nowe lokalne miejsca pracy związane z taką produkcją [NIK 2014].

Spadek liczby etatów w niektórych branżach związanych z sektorami biopaliw transportowych bezpośrednio jest związany ze spadkiem zainteresowania produkcją biopaliw 1 . generacji, tj. bioetanolu i biodiesla, oraz zmniejszającą się opłacalnością prowadzenia takiej działalności. Szansą na wzrost zatrudnienia w sektorach biopaliw transportowych w Polsce jest perspektywa rozpowszechnienia na skalę przemysłową, propagowanych przez Unię Europejską, biopaliw wyższych generacji, przede wszystkim bioetanolu lignocelulozowego.

\section{POLSKIE BIOPALIWA TRANSPORTOWE W ASPEKCIE KONKURENCYJNOŚCI MIĘDZYNARODOWEJ}

Konkurencyjność biopaliw jest warunkowana przede wszystkim cenami konwencjonalnych nośników energii. Wzrost cen ropy powoduje wzrost cenowej konkurencyjności biopaliw, spadek wpływa na jej ograniczenie. Zależność ta wynika z relatywnie wysokich kosztów produkcji bioenergii, z reguły znacznie przewyższających pozyskanie surowców konwencjonalnych. Jednak w niektórych miejscach na świecie produkcja biopaliw staje się bardzo opłacalna, czego przykładem jest Brazylia uznawana za potentata w produkcji bioetanolu. Przewaga konkurencyjna biopaliw brazylijskich wynika przede wszystkim z zasobności kraju w surowce energetyczne używane do produkcji bioetanolu oraz z niższych kosztów jego produkcji i przetwórstwa surowców (trzciny cukrowej) [Golisz 2014].

W momencie akcesji Polski do UE krajowa produkcja biopaliw sprowadzała się do wytwarzania bioetanolu w małych zakładach opartych na gorzelniach rolniczych oraz niewielkiej produkcji biodiesla na własne potrzeby wytwórców (gospodarstw rolnych). W związku z tym polscy producenci, charakteryzujący się niskimi zdolnościami wytwórczymi, nie dysponowali siłą przetargową na arenie międzynarodowej. Ze względu na niską konkurencyjność (małe moce oraz wyższe koszty produkcji), aspekty organizacyjno-prawne, energetyczne oraz ekologiczne małe zakłady zostały wyparte, a polski rynek zdominowany przez zakłady bardziej konkurencyjne, osiągające efekt skali.

Ważny i negatywny aspekt funkcjonowania i rozwoju zdolności produkcyjnych oraz rynku biopaliw transportowych w Polsce stanowi zapóźnienie, które wynosi około 6-15 lat względem czołówki producentów z UE. Taki stan nie wpływa pozytywnie na zdolności 
konkurowania (eksportu) polskich wytwórców w UE oraz na arenie globalnej. Pomimo opóźnienia technologii, które obecnie funkcjonują w Polsce, poziom krajowych badań dotyczących nowoczesnych technologii umożliwiających produkcję biopaliw wyższych generacji charakteryzuje się wysokim stopniem zaawansowania, dorównującym rozwiniętej Europie. W Polsce powstają nowe produkty/technologie związane z paliwami alternatywnymi, np. otwarty pod koniec 2016 r. Zakład Produkcji Paliw Syntetycznych z Bioetanolu „EkoBenz”, zlokalizowany w Bogumiłowie (woj. łódzkie). W zakładzie jako surowiec do procesu produkcji paliw syntetycznych w instalacji ETG (ang. ethanol to gasoline) jest wykorzystywany alkohol etylowy wytworzony w całości z biomasy. Proces produkcji charakteryzuje się niskim zapotrzebowaniem na zewnętrzne źródła energii, co znacząco ogranicza emisję gazów cieplarnianych i poprawia wskaźniki samego procesu technologicznego. EkoBenz to innowacyjna, pierwsza na świecie instalacja tego typu ze zdolnościami produkcyjnymi na poziomie 22,5 tys. t/rok [www.ekobenz.pl/technologia].

W odniesieniu do konkurencyjności biopaliw produkowanych na terenie UE, w tym $\mathrm{w}$ Polsce, istotny problem stanowi dumpingowy import biopaliw. W związku z wieloma wszczętymi postępowaniami antydumpingowymi Komisja Europejska realizuje działania protekcjonistyczne, jednak są to działania o charakterze doraźnym, podejmowane po wystąpieniu zjawiska, a nie prewencyjnym, w postaci sprawnie działających mechanizmów kontrolnych uniemożliwiających import biopaliw po dumpingowych cenach. Przykładem takich działań są m.in. cła antydampingowe i wyrównawcze obowiązujące od 2009 r. w przywozie biodiesla z USA [Kaliszuk 2015]. Import biopaliw z krajów wykorzystujących dumping zaburza konkurencyjność europejskich wytwórców.

Problem z konkurencyjnością polskich biopaliw, poza relatywnie wysokimi kosztami produkcji, wynika także z ich cech związanych z rzeczywistą redukcją emisji $\mathrm{CO}_{2}$. Aspekt ten, budzący wiele kontrowersji, zostanie zweryfikowany za pomocą narodowego celu redukcyjnego (NCR). Podmioty realizujące NCR są zobowiązane do zapewnienia minimalnej wartości ograniczenia emisji gazów cieplarnianych w cyklu życia paliw, 4\% w $2017 \mathrm{r}$. oraz 6\% w 2020 r. (względem poziomu z 2010 r.). Istnieją ogromne obawy o 2020 r., gdy dojdzie do konfrontacji z rzeczywistą redukcją emisji polskich zakładów produkujących biopaliwa. Za niezrealizowanie NCR naliczane będą kary, których wysokość zależy m.in. od średniej ceny uprawnienia do emisji gazów cieplarnianych.

Po wejściu Polski do UE w sektorach związanych z produkcją biopaliw transportowych panował powszechny optymizm. Zakładano, że ze względu na bogatą tradycję związaną z produkcją etanolu oraz dużą zasobność w surowce do produkcji biokomponentów Polska ma szansę stać się znaczącym producentem i eksporterem biopaliw. Funkcjonujące początkowo mechanizmy wsparcia, ulgi podatkowe i zwolnienia z opłaty paliwowej nie przyniosły oczekiwanych rezultatów, a popyt na biopaliwa ciekłe i biokomponenty polskiego pochodzenia nie zwiększył się. Krajowi producenci nie są konkurencyjni na rynku - koszty wytworzenia biopaliw w Polsce są wyższe niż ceny, które są za nie oferowane. Taka sytuacja powoduje, że zdolności produkcyjne polskich wytwórców nie są w pełni wykorzystywane, a ponad połowa biokomponentów obecnych na polskim rynku pochodzi $\mathrm{z}$ importu. Trend ten przewidywany jest co najmniej do 2020 r. [NIK 2014]. 


\section{PRZYSZŁOŚĆ BIOPALIW TRANSPORTOWYCH W POLSCE}

Przyszłość sektorów biopaliw transportowych w Polsce związana była i jest $\mathrm{z}$ trendami w UE. W latach 2005-2010 przewidywano znaczący udział wodoru w wykorzystaniu paliw transportowych. Od 2011 roku zmieniło się podejście, w tym metodyka badań redukcji emisji $\mathrm{CO}_{2}$, i większą uwagę zwrócono na biopaliwa nowej generacji, produkowane $\mathrm{z}$ surowców niejadalnych. Wprowadzenie na rynek tych biopaliw przewidywano po $2015 \mathrm{r}$. Planuje się, że w 2020 r. skończy się promocja biopaliw produkowanych z surowców jadalnych, promowane będą tylko biopaliwa produkowane z wydajniejszych surowców niejadalnych [Gonzales 2005, Kupczyk i in. 2007, Londo i in. 2010].

Obowiązujące wymagania, wynikające z unijnych dyrektyw, są bardzo rozbudowane i dotyczą m.in.:

- uzyskania do 2020 r. 10\% udziału energii z OZE w końcowym zużyciu energii w transporcie,

- $\quad$ konieczności spełniania obowiązujących KZR w celu zaliczenia produkowanych biopaliw na poczet NCW,

- obowiązku realizacji NCR (rzeczywista wielkość redukcji emisji $\mathrm{CO}_{2}$ ),

- dodatkowych ograniczeń związanych z maksymalnym udziałem biopaliw 1. generacji. Wymagania te powodują, że polskie sektory biopaliw transportowych w najbliższych latach czeka wiele wyzwań. Ponieważ polski rynek biopaliw transportowych bazuje na surowcach jadalnych (m.in. na rzepaku) wykorzystywanych w produkcji biokomponentów, to obowiązek ograniczenia tych źródeł może spowodować, że Polska nie będzie w stanie zrealizować unijnych zobowiązań. Równocześnie w Polsce brakuje rozwiązań oraz infrastruktury pozwalającej na wykorzystanie innych, alternatywnych źródeł w transporcie (np. energii elektrycznej) [Wiśniewski 2016b]. Według ekspertów branżowych, biopaliwa zaawansowane wyższych generacji mogą, a nawet powinny stanowić istotną część polskiego miksu energetycznego paliw transportowych. Jednak sektor ten powinien przejść ewolucję, nie zaś rewolucję, w taki sposób, aby konwersja ta w perspektywie długoterminowej uwzględniała wszelkie aspekty towarzyszące, a wśród nich m.in. opłacalność, rozwój technologiczny, podtrzymanie funkcjonowania dotychczasowego łańcucha dostaw, a także realne możliwości prowadzenia na skalę przemysłową produkcji [Czubiński 2016].

Zagadnieniu implementacji biopaliw 2. generacji poświęcono specjalne badania eksperckie $^{6}$, wykonane w znacznej mierze przez autorów tej publikacji. Zdaniem ankietowanych w ramach badania ekspertów, najbardziej prawdopodobnym okresem uruchomienia produkcji biopaliw 2. generacji w Polsce będą lata 2021-2025. Eksperci nie wykluczyli jednak, że wdrożenie biopaliw 2. generacji może nastąpić w jeszcze późniejszym okresie. Prawdopodobieństwo wdrożenia w Polsce biopaliw 2. generacji przed 2020 r. według ekspertów ocenione zostało stosunkowo nisko. W ich opinii wycofanie z Polski biopaliw 1. generacji odbędzie się najprawdopodobniej w latach 2020-2040 [Krzywonos i in. 2015].

6 Ankietę przeprowadzono wśród osób z Krajowej Izby Biopaliw, Krajowej Izby Paliw Alternatywnych, Związku Gorzelni Polskich i Bioagry. 


\section{OCENA WARTOŚCI (ATRAKCYJNOŚCI) SEKTORÓW BIOPALIW TRANSPORTOWYCH}

Każdy sektor w poszczególnych stadiach rozwoju charakteryzuje się pewnymi cechami, które wpływają na jego wartość (atrakcyjność). Wartość danego sektora można określić metodą punktową wielokryterialną M.E. Portera za pomocą oceny zestawu kryteriów, ważnych z perspektywy ocenianego sektora. Oceny takiej dokonują osoby bezpośrednio związane z sektorem z rozległą wiedzą na jego temat. Poszczególne kryteria są oceniane w skali od 0 do 3. Końcowa wartość badanego sektora, wyrażona w procentach, jest ilorazem sumy średnich arytmetycznych ocen eksperckich poszczególnych kryteriów oraz maksymalnej, możliwej do uzyskania wartości.

Wartość (atrakcyjność) sektorów biopaliw transportowych zależy od uwarunkowań prawnych, międzynarodowych, rynkowych, społecznych, techniczno-technologicznych oraz stopnia konkurencji w badanych sektorach, sektorach pokrewnych, konkurencyjnych (substytuty) oraz surowcowych [Gierszewska, Romanowska 2002].

W celu oceny atrakcyjności sektorów biopaliw transportowych (bioetanolu 1. ${ }^{7}$ i 2. generacji $^{8}$ oraz biodiesla 1. generacji) w Polsce w 2016 r., posłużono się zestawem 15 wyselekcjonowanych kryteriów, uznanych jako ważne z perspektywy ocenianych sektorów. Do kryteriów tych należą m.in.: wielkość sektora, przewidywana stopa wzrostu sektora, ostrość walki konkurencyjnej, bariery wejścia, dostępność surowców, marża zysku, przychylność polityki UE oraz społeczne postrzeganie sektora (wykaz kryteriów zawarto w tabeli 3.). Eksperci dokonywali oceny za pomocą tzw. siatki oceny atrakcyjności, którą wraz z uzyskanymi wynikami przedstawiono w tabeli 3 . W wyniku przeprowadzonych badań otrzymano ocenę $33,43 \%$ dla sektora bioetanolu 1. generacji, 26,57\% dla sektora biodiesla 1. generacji oraz $69,50 \%$ dla sektora bioetanolu 2. generacji. Wartość sektorów biopaliw transportowych 1. generacji (bioetanolu i biodiesla) jest przedmiotem badań od 2007 r., a bioetanolu 2. generacji od 2013 roku9. Wyniki przeprowadzanych badań były przedstawiane w wielu publikacjach [m.in. Golisz 2013, Borowski i in. 2016, Sikora i in. 2016], a zostały zestawione z wartościami uzyskanymi za 2016 r. na rysunku 2.

Z danych przedstawionych na rysunku 2. wynika, że w latach 2006-2007 wyniki były bardzo obiecujące. Wówczas sektory biopaliw transportowych 1. generacji oceniane były jako stosunkowo atrakcyjne elementy gospodarki. W przypadku biodiesla wartość sektora osiągnęła poziom prawie $68 \%$, a bioetanolu $62 \%$. Jednak najnowsze wyniki badań atrakcyjności sektorów biopaliwowych nie zachęcają do inwestowania w biopaliwa 1. generacji. Z badań przeprowadzonych w 2016 r. wynika, że atrakcyjność zarówno sektora biodiesla, jak i bioetanolu 1. generacji spadła ponaddwukrotnie względem 2007 r. Od 2013 r. zakresem badań atrakcyjności sektorów biopaliw transportowych objęto również sektor bioetanolu 2. generacji, którego atrakcyjność stale wzrasta.

$\mathrm{Na}$ tle biopaliw 1. generacji znacznie korzystniej przedstawia się sytuacja biopaliwa 2. generacji, którym jest bioetanol lignocelulozowy. Jednak jego produkcja w Polsce obecnie nie występuje w dużej skali przemysłowej i charakteryzuje się wyższymi, względem biopaliw 1. generacji, kosztami wytworzenia. Produkcja biopaliw 2. generacji stanowi duże wyzwanie technologiczne. Na początku obecnego stulecia zbudowano kilkanaście

\footnotetext{
7 W ocenie pominięto gasnący sektor bioetanolu wytwarzanego w sposób 2-fazowy (1. faza - gorzelnia rolnicza, 2. zakład odwadniający), ponieważ w Polsce ma on marginalne znaczenie rynkowe. Badaniami objęto tylko sektor bioetanolu 1. generacji produkowanego w sposób 1-fazowy.

8 Sektor obecnie funkcjonuje w Polsce jedynie w skali doświadczalnej.

9 Wyniki systematycznie publikowano w czasopiśmie „Gospodarka Materiałowa i Logistyka”.
} 


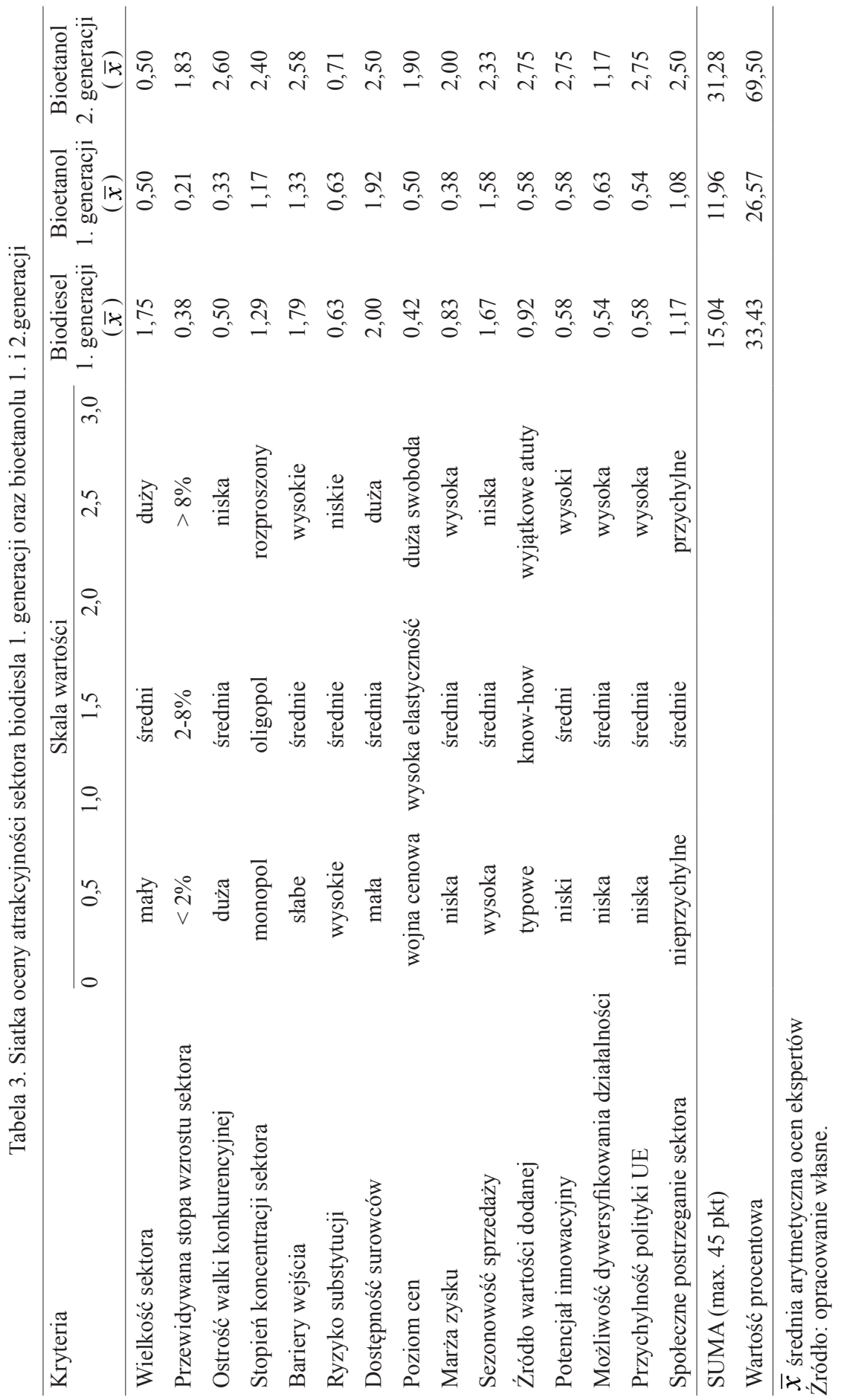




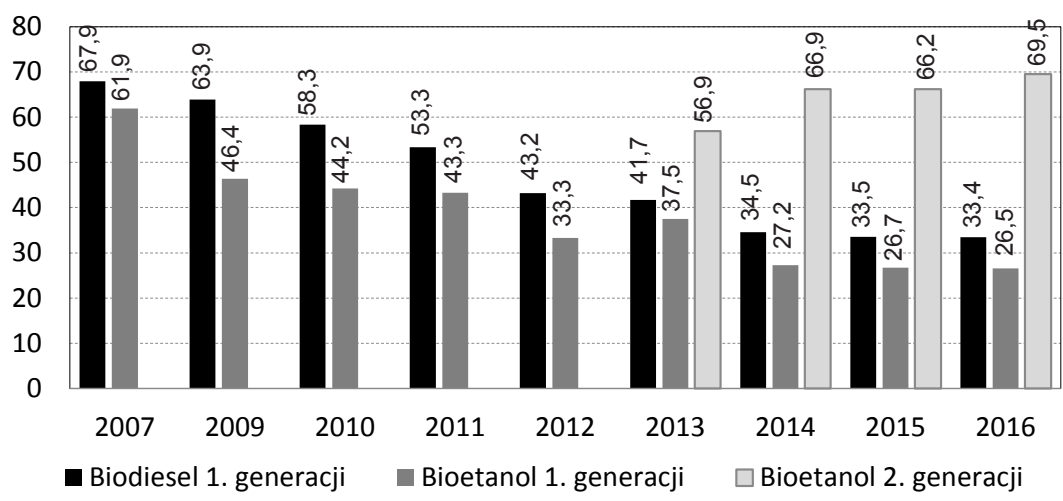

Rysunek 2. Atrakcyjność sektorów biopaliw transportowych w Polsce w latach 2007-2016 Źródło: opracowanie własne.

obiektów o małej skali produkcji. W UE funkcjonuje już kilka obiektów produkujących bioetanol 2. generacji na skalę przemysłową, jednak przykładów takich biorafinerii nie jest dużo, a w Polsce do tej pory nie funkcjonuje żaden tego rodzaju obiekt. W Polsce na implementację obiektów, które pozwolą w sposób efektywny (ekonomicznie i ekologicznie) otrzymywać biopaliwo lignocelulozowe, należy jeszcze poczekać [Borowski i in. 2016].

Ważny czynnik popytowy dla biopaliw transportowych stanowią wprowadzone unijnymi dyrektywami wymuszenia obligatoryjności wykorzystania wskaźników ilościowych (tj. $\mathrm{NCW}$ oraz NCR $)^{10}$. Ponadto z perspektywy oceny sektora bioetanolu 2. generacji istotnym czynnikiem popytowym jest możliwość podwójnego zaliczenia biopaliw wytworzonych m.in. z odpadów, pozostałości czy materiałów lignocelulozowych na poczet realizacji NCW. Dodatkowo na atrakcyjność biopaliw wyższych generacji wpływa w znaczący sposób najnowsza dyrektywa 2015/151/WE ustanawiająca, że w celu obliczania udziału energii powstającej przy wykorzystaniu OZE we wszystkich rodzajach transportu (min. 10-procentowy udział w 2020 r.) minimalna ilość biopaliw wyższych generacji wynosić ma 3\%. Omówione czynniki pozytywnie wpływające na atrakcyjność sektora bioetanolu 2. generacji jednocześnie hamują rozwój sektorów biopaliw 1. generacji.

W kontekście atrakcyjności sektorów biopaliw transportowych w Polsce, poza konwencjonalną produkcją bioetanolu oraz estrów metylowych w krajowych zakładach, należy zwrócić uwagę na instalacje oraz technologie hybrydowe pracujące w systemie kaskadowym. Przewiduje się, że to one będą bardzo atrakcyjne. Istota takich rozwiązań polega na stworzeniu sprawnie działających systemów, powiązanych surowcowo i energetycznie, obejmujących wytwórców bioetanolu, biogazownie oraz urządzenia towarzyszące. Ich ideą jest wykorzystanie odpadów generowanych podczas produkcji biopaliw jako substratów wykorzystywanych w biogazowniach, a energii powstającej z biogazu w technologicznych procesach zachodzących w instalacjach produkujących bioetanol. Przykładem hybrydowego rozwiązania jest instalacja zlokalizowana w Piaszczynie (woj. pomorskie). Zastosowana technologia pozwala na osiągnięcie efektu synergii i umożliwia uzyskanie pozytywnych efektów, m.in. w postaci zmniejszenia kosztów produkcji bioetanolu o około $40 \%$ (z 1 zł do $0,63 \mathrm{zl} / 1 \mathrm{dm}^{3}$ ) [Gostomczyk 2015].

10 Bardzo wysokie kary za niewykonanie NCW, NCR. 


\section{WNIOSKI}

1. Regulacje prawne dotyczące polskiego rynku biopaliw transportowych są regularnie przystosowywane do regulacji prawnych UE. Obecnie największe wyzwanie stanowi dyrektywa 2015/1513/WE, która ustanawia maksymalną ilość biopaliw 1. generacji w 2020 r. na poziomie 7\%. Biorąc pod uwagę fakt, że polski rynek biopaliw transportowych bazuje na surowcach jadalnych, obowiązek ograniczenia tych źródeł może spowodować, że Polska nie będzie w stanie zrealizować unijnych zobowiązań.

2. Potencjał wytwórczy polskich producentów biokomponentów jest wykorzystywany w nieznacznym stopniu - średnio na poziomie 27\% (bioetanol) oraz 57\% (estry metylowe) i nie ma przesłanek zmian w tym zakresie.

3. Rozwój energetyki odnawialnej jest korzystny dla rynku pracy. Miejsc pracy i specjalności w energetyce odnawialnej można szukać we wszystkich sektorach na różnych etapach wdrażania idei energetyki odnawialnej. Szacuje się, że w krajowych sektorach związanych z produkcją surowców biokomponentów jest zatrudnionych 60-65 tys. osób.

4. Najprawdopodobniej w 2020 r. skończy się promocja biopaliw produkowanych z surowców jadalnych, a będą promowane biopaliwa produkowane $\mathrm{z}$ wydajniejszych surowców niejadalnych.

5. Wynikające z unijnych dyrektyw wymagania względem państw członkowskich są bardzo rozbudowane i powodują, że polskie sektory biopaliw transportowych w najbliższych latach czeka wiele wyzwań.

6. Z prowadzonych systematycznie badań obejmujących atrakcyjność sektorów biopaliw transportowych 1. generacji wynika, że obniżyła się ona wyraźnie. Spadek oceny ponaddwukrotnie, nie zachęca do inwestowania w ten sektor.

7. W porównaniu do biopaliw 1. generacji znacznie korzystniej przedstawia się sytuacja bioetanolu lignocelulozowego, jednak jego produkcja w Polsce nie występuje skali przemysłowej i charakteryzuje się wyższymi względem biopaliw 1. generacji kosztami wytworzenia.

\section{LITERATURA}

Arcipowska Aleksandra, Grzegorz Kunikowski, Katarzyna Michałowska-Knap, Anna Oniszk-Popławska, 2013: [R]ewolucja energetyczna dla Polski. Scenariusz zaopatrzenia Polski w czyste nośniki energii w perspektywie długookresowej, Fundacja Greenpeace Polska, Warszawa, s. 51.

Borowski Piotr, Adam Kupczyk, Karol Tucki, 2016: Prognoza i atrakcyjność sektorów biopaliw transportowych w Polsce, [w] Wyniki wybranych badań przeprowadzonych w ramach projektu WOOD$T E C H$, red. Stanowiła Karpiński, Oficyna Wydawniczo-Poligraficzna Adam, Warszawa, s. 90-96.

Borowski Piotr, Jakub Gawron, Ewa Golisz, 2014: Wptyw redukcji emisji CO, na funkcjonowanie sektorów biopaliw transportowych w Polsce, Oficyna Wydawniczo-Poligraficzna Adam, Warszawa, s. 239.

Czubiński Tomasz, 2016: Rzepakowcy o biopaliwach, http://www.topagrar.pl/arti cles/top-uprawa/ rzepakowcy-o-biopaliwach, dostęp: 28.09.2016.

Dyrektywa Parlamentu Europejskiego i Rady (UE) 2015/1513 z dnia 9 września 2015 r. zmieniająca dyrektywe 98/70/WE odnoszaca się do jakości benzyny i olejów napędowych oraz zmieniająca dyrektywę 2009/28/WE w sprawie promowania stosowania energii ze źródeł odnawialnych, Dz.U. UE L 2015.293.1.

Dyrektywa Parlamentu Europejskiego i Rady 2003/30/WE z dnia 8 maja 2003 r. w sprawie wspierania użycia w transporcie biopaliw lub innych paliw odnawialnych, Dz.U. UE L 2003.123.42.

Dyrektywa Parlamentu Europejskiego i Rady 2009/28/WE z dnia 23 kwietnia 2009 r. w sprawie promowania stosowania energii ze źródeł odnawialnych zmieniająca $i$ w następstwie uchylająca dyrektywy 2001/77/WE oraz 2003/30/WE, Dz.U. UE L 2009.140.16. 
Dyrektywa Parlamentu Europejskiego i Rady 2009/30/WE z dnia 23 kwietnia 2009 r. zmieniajaca dyrektywę 98/70/WE odnoszaca się do specyfikacji benzyny i olejów napędowych oraz wprowadzająca mechanizm monitorowania i ograniczania emisji gazów cieplarnianych oraz zmieniajaca dyrektywę Rady 1999/32/WE odnoszaca się do specyfikacji paliw wykorzystywanych przez statki żeglugi śródlądowej oraz uchylająca dyrektywę 93/12/EWG, Dz.U. UE L 2009.140.88.

EurObserv'ER, 2015: Biuletyn energii odnawialnej. Biopaliwa transportowe. https://www.eurobserv-er. org/biuletyn-energii-odnawialnej-biopaliwa-transportowe-2015, dostęp: 06.03.2017.

Gierszewska Grażyna, Maria Romanowska, 2002: Analiza strategiczna przedsiębiorstwa, PWE, Warszawa, s. 352.

GUS, 2016: Wyniki produkcji roślinnej w 2015 r. http://www.stat.gov.pl, dostęp: 06.03.2017.

Golisz Ewa, 2013: Historia, stan aktualny i perspektywy gorzelni rolniczych w Polsce, „Przemysł Fermentacyjny i Owocowo-Warzywny", t. 57, z. 1, s. 23-25.

Golisz Ewa, 2014: Konkurencyjność brazylijskiego bioetanolu na świecie, ,Zeszyty Naukowe SGGW w Warszawie. Problemy Rolnictwa Światowego.”, t. 14, z. 1, s. 16-24.

Gonzales Finat, 2005: Biofuels for Transport: Challenge\& Achievements. The 1st meeting of the Biofuels Research Advisory Council (BIOFRAC) in support of the European Technology Platform for Biofuels, European Commision, Brussele, 15 June 2005.

Gostomczyk Waldemar, 2013: Rynek pracy w Polsce i Unii Europejskiej w sektorze odnawialnych źródeł energii, [w] Ekonomia i zarządzanie energia a rozwój gospodarczy, red. Kazimierz Pająk, Agnieszka Ziomek, Sławomir Zwierchlewski, Wydawnictwo Adam Marszałek, Toruń, s. 225-235.

Gostomczyk Waldemar, 2015: Rynek biogazu rolniczego w Polsce $i$ wykorzystywane surowce w latach 2011-2014, „Zeszyty Naukowe SGGW w Warszawie. Problemy Rolnictwa Światowego”, t. 15, z. 3, s. 30-39.

Jarosz Leszek, 2010: Informacja uzyskana od Prezesa Krajowej Rady Gorzelnictwa i Produkcji Biopaliw.

Kaliszuk Ewa, 2015: Wzrost zielonego protekcjonizmu, „Unia Europejska.pl”, z. 6, s. 45-62.

Koć Patryk, Jarosław Osiak, 2016: Wprowadzenie, [w] Odnawialne źródta energii w Polsce. Wybrane wyzwania w obszarze technologii i finansów, red. Małgorzata Kaliczyńska, Przemysłowy Instytut Automatyki i Pomiarów PAP, Warszawa, s. 5-6.

Kowalski Marcin, 2014: Zrównoważone rozwiązania w transporcie miejskim, http://www.ekosamorzadowiec.pl/pl/od_eko_samorzadu_do_eko_spoleczenstwa/artykuly_ekspercke/2045.html, dostęp: 20.12.2016.

Krzywonos Małgorzata, Jacek Skudlarski, Adam Kupczyk, Janusz Wojdalski, Karol Tucki, 2015: Prognoza rozwoju sektora biopaliw transportowych w Polsce w latach 2020-2030, „Przemysł Chemiczny", t. 94, z. 12, s. 2218-2222.

Kuczyński Szymon, 2016: Wypowiedź zamieszczona na stronie internetowej http://www.portalspozywczy.pl/zboza/wiadomosci/rozwoj-upraw-rzepaku-w-polsce-to-dowod-na-pozytywny-wplywbiopaliw-na-rolnictwo, 133128.html, dostęp: 06.03.2017.

Kupczyk Adam, Marc Londo, Grzegorz Wiśniewski, 2007: Rola Polski w planie działania UE dla biopaliw do $2020 \mathrm{r}$. Analiza wstęnych wyników projektu UE REFUEL. Warsztaty „Biomasa i Biopaliwa w Polsce”, Projekt PSO PPA, IPiEO, Warszawa, 19 czerwca 2007.

Kuziemska Beata, Krystyna Pieniak-Lendzion, Joanna Trębicka, Wiesław Wiermiej, Paulina Klej, 2015: Alternatywne źródła energii, „Zeszyty Naukowe Uniwersytetu Przyrodniczo-Humanistycznego w Siedlcach. Seria Administracja i Zarządzanie”, t. 33, z. 106, s. 89-107.

Londo Marc, Sander Lensink, Andre Wakker i inni. 2010: The REFUEL EU Road map for biofuels in transport. Application of the project's tools to some short-term policy issues, „Biomass\&Bioenergy", t. 34, z. 2 s. 244-250.

NIK (Najwyższa Izba Kontroli), 2014: Stosowanie biopaliw i biokomponentów w transporcie. Informacja o wynikach kontroli. NIK, Warszawa.

Pielecha Jacek, Markiesz-Guranowska Agnieszka, 2014: Emisja zanieczyszczeń z pojazdów samochodowych a parametry ruchu drogowego, Wyd. Oficyna Wydawnicza Politechniki Warszawskiej, Warszawa.

Rozporządzenie Rady Ministrów z dnia 13 sierpnia 2013 r. w sprawie wysokości wspótczynników redukcyjnych na lata 2014 i 2015, Dz.U.2013 poz. 1052.

Rozporzadzenie Rady Ministrów z dnia 20 kwietnia 2015 r. w sprawie wysokości wspólczynników redukcyjnych na lata 2016 i 2017, Dz.U.2015 poz. 631.

Rozporzadzenie Rady Ministrów z dnia 23 lipca 2013 r. w sprawie Narodowych Celów Wskaźnikowych na lata 2013-2018, Dz.U. z 2013 poz. 918. 
Sikora Michał, Joanna Stasiak-Panek, Adam Kupczyk, Magdalena Zubrzycka, Anna Bączyk, Joanna Mączyńska, 2016: Aktualny stan i atrakcyjność sektorów biopaliw w Polsce, „Przemysł Fermentacyjny i Owocowo-Warzywny", t. 60, z. 5, s. 25-27.

Szeliga Mariusz, 2016: Wypowiedź zamieszczona na stronie internetowej http://www.portalspozywczy. pl/zboza/wiadomosci/r ozwoj-upraw-rzepaku-w-polsce-to-dowod-na-pozytywny-wplyw-biopaliwna-rolnictwo,133128.html, dostęp: 06.03.2017.

Taras Dariusz, 2016: Szykuje się rozwój biopaliw wyższej generacji. http://www.teraz-srodowisko. pl/aktualnosci/Szykuje-sie-rozwoj-biopaliw-wyzszej-generacji-1790.html, dostęp: 20.12.2016.

Ustawa z dnia 25 sierpnia 2006 r. o biokomponentach i biopaliwach ciektych, Dz.U. z 2015 r. poz. 775 oraz z 2016 r. poz. 266 i 1165.

Ustawa z dnia 25 sierpnia 2006 r. o systemie monitorowania i kontrolowania jakości paliw, Dz.U. z 2014 r. poz. 1728, z 2015 r. poz. 1361 oraz z 2016 r. poz. 266, 542, 1165.

Ustawa z dnia 27 maja 2011 r. o zmianie ustawy o systemie monitorowania i kontrolowania jakości paliw oraz niektórych innych ustaw, Dz.U.2011, nr 153, poz. 902.

Wąsiewski Grzegorz, 2015. Nowe wyzwania przed rynkiem biopaliw. http://www.rp.pl/Firma/311159971-Nowe-wyzwania-przed-rynkiem-biopaliw.html\#ap-2, dostęp: 28.09.2016.

Wiśniewski Grzegorz, 2016a: Ile i kto zapłaci za niewypetnienie polskich zobowiazań wobec UE $w$ zakresie OZE, http://odnawialny.blogspot.fr/2016/12/ile-i-kto-zapaci-za-niewypenienie.html, dostęp: 06.03.2017.

Wiśniewski Grzegorz, 2016b: Jak Polska realizuje unijne zobowiąania dotyczace energii z OZE? http://biznesalert.pl/jak-polska-realizuje-unijne-zobowiazania-dotyczace-energii-z-oze, dostęp: 28.09.2016.

Zakrzewski Tadeusz, 2014: Informacja uzyskana od byłego Prezesa Krajowej Izby Biopaliw.

Zamojski Henryk, 2014: Informacja uzyskana od Prezesa Krajowej Izby Paliw Alternatywnych.

Żak Agata, Ewa Golisz, Karol Tucki, Piotr Borowski, 2014: Perspektywy rozwoju sektora biopaliw w Polsce na tle norm emisji $\mathrm{CO}_{2}$, ,Journal of Agribusiness and Rural Development”, t. 33, z. 3, s. 299-311.

Żołądkiewicz Agnieszka, 2016: Ekonomiczno-ekologiczne aspekty produkcji biopaliw ciektych, „Roczniki Naukowe SERiA", t. 18, z. 3, s. 426-431.

\title{
Adam Kupczyk, Joanna Mączyńska, Michał Sikora, Karol Tucki, Tomasz Żelaziński \\ THE SITUATION, PROSPECTS AND LEGAL CONDITIONS OF THE BIOFUELS FOR TRANSPORT SECTORS IN POLAND
}

\begin{abstract}
Summary
The current state and the future of the biofuels for transport sectors in Poland were presented in the paper. Because of the importance of legal conditions, crucial directives and acts affecting the shape of these sectors were discussed. The scoring multicriteria M.E. Porter method was used to research attractiveness of the national biofuel sectors, i.e. the sectors of biodiesel and bioethanol produced from edible material (so-called first generation biofuels) as well as the sector of bioethanol produced from inedible material, mainly from lignocellulose (so-called second generation biofuel). Various factors of macro- and microenvironment of first generation biofuels caused regular reduction of their attractiveness. However, the sector of second generation bioethanol, which is not produced at industrial scale in Poland now, is characterized by relatively high and growing attractiveness.
\end{abstract}

$$
\begin{array}{r}
\text { Adres do korespondencji: } \\
\text { Katedra Organizacji i Inżynierii Produkcji } \\
\text { ul. Nowoursynowska 164,02-787 Warszawa,tel. +48 } 225934560 \text { (61) } \\
\text { e-mail: koip@sggw.pl, joanna_maczynska@sggw.pl }
\end{array}
$$

\section{Podziękowania}

Zespół autorów kieruje szczególne podziękowania do osób z Krajowej Izby Biopaliw, Krajowej Izby Paliw Alternatywnych oraz Związu Gorzelni Polskich za możliwość wymiany pogladów, stużenie rada, wsparcie oraz pomoc przy realizacji badań związanych z ocena atrakcyjności sektorów biopaliw transportowych w Polsce. 